\title{
PENERAPAN MODEL KONTEKSTUAL PEMBELAJARAN BATUAN PADA SMAN 9 BINSUS MANADO
}

\author{
Denny Maliangkay \\ Jurusan Geografi, Fakultas Ilmu Sosial, Universitas Negeri Manado
}

\begin{abstract}
Abstrak
Tujuan pengabdian ini adalah untuk mengetahui penerapan CTL dan lingkungan sebagai sumber belajar dalam meningkatkan pemahaman siswa dalam pembelajaran geografi khususnya tentang jenis batuan. Kegiatan dilaksanakan selama 3 bulan. Siklus I, guru menunjukkan jenis batuan sambil menjelaskan dan siswa mengerjakan kartu soal, siklus II siswa mengamati, mengidentifikasi, dan mengelompokan jenis batuan dengan mengerjakan tabel kerja pada LKS secara berkelompok di luar kelas/lingkungan sekolah kemudian mempresentasikan hasil diskusi kelompok dan siklus III, siswa ditugaskan membawa 10 jenis batuan yang berbeda dari rumah kemudian diamati, diidentifikasi dan dikelompokan dengan mengerjakan LKS lalu dipresentasikan di depan kelas sambil menunjukkan jenis batuan satu persatu secara individu sesuai LKS. Hasil menunjukkan bahwa terjadi peningkatan pemahaman siswa akibat motivasi dan aktifitas belajar siswa dalam melakukan pengamatan, mengidentifikasi atau mengelompokan jenis batuan dan mengerjakan soal LKS baik secara kelompok maupun individu. Pada akhir tindakan, berdasarkan indikator keberhasilan terbukti bahwa tindakan yang diberikan berhasil meningkatkan pemahaman siswa hingga mencapai ketuntasan secara klasikal. Pada post test sebelum CAR (classroom action research) ketuntasan belajar siswa adalah 20\%, setelah diberikan tindakan post test pada siklus I ketuntasannya 48,57\%, siklus II 74,20\% dan pada siklus III 88,57\%. Oleh karena itu, penulis menyarankan apabila hendak meningkatkan pemahaman siswa tentang jenis batuan dapat menerapkan pendekatan CTL.

Kata Kunci: contextual teaching and learning, pembelajaran, batuan.
\end{abstract}

\section{PENDAHULUAN}

\section{Analisis Situasi}

Pendidikan nasional dewasa ini menghadapi masalah penting yakni masih tergolong rendahnya kualitas pendidikan pada hampir semua strata pendidikan. Menurut Sanjaya (2005), rendahnya kualitas pendidikan nasional mendorong komponen pendidikan untuk melakukan perubahan, dan salah satu unsur penting yang perlu dikembangkan adalah pengembangan kurikulum dalam konteks reformasi pendidikan. Cecep (2002) menjelaskan bahwa untuk mengatasi masalah rendahnya kualitas pendidikan telah ditempuh berbagai upaya nyata melalui berbagai kegiatan seperti; perubahan kurikulum, perbaikan sarana dan prasarana pembelajaran, penerapan manajemen mutu pendidikan dan usahalainnya yang berorientasi peningkatan kualitas pendidikan, namun kenyataan menunjukkan perubahan dan kemajuan yang diharapkan belum menunjukkan perubahan dan peningkatan yang signifikan.

Kencenderungan dewasa ini untuk kembali pada pemikiran bahwa anak akan belajar lebih baik jika lingkungan diciptakan alamiah. Belajar akan lebih bermakna jika anak didik 'mengalami' apa yang dipelajari, bukan 'mengetahui'-nya. Pembelajaran yang berorientasi target penguasaan materi 
terbukti berhasil dalam kompetisi 'mengingat' jangka pendek, tetapi gagal dalam membekali anak memecahkan persoalan dalam kehidupan jangka panjang. Kontekstual hanya sebuah strategi pembelajaran, seperti halnya dengan strategi pembelajaran yang lain, kontekstual dikembangkan dengan tujuan agar pembelajaran berjalan lebih produktif dan berkmakna. Pendekatan kontekstual dapat dijalankan tanpa harus mengubah kurikulum dan tatanan yang ada.

Pendekatan kontekstual (Contextual Teaching and Learning/CTL) merupakan konsep belajar yang membantu guru mengaitkan antara materi yang diajarkannya dengan situasi dunia nyata siswa dan mendorong siswa membuat hubungan antara pengetahuan yang dimilikinya dengan penerapannya dalam kehidupan mereka sebagai anggota keluarga dan masyarakat. Dengan konsep itu hasil pembelajaran diharapkan lebih bermakna bagi siswa SMA Negeri 9 Binsus Manado. Proses pembelajaran berlangsung alamiah dalam bentuk kegiatan siswa bekerja dan mengalami, bukan transfer pengetahuan dari guru ke siswa. Dalam konteks itu siswa perlu mengerti apa makna belajar, apa manfaatnya, dalam status apa mereka, dan bagaimana mencapainya.

Penerapan model pembelajaran kontekstual, tugas guru adalah membantu mencapai tujuannya. Maksudnya, guru lebih banyak berurusan dengan strategi dari pada memberi informasi. Tugas guru mengelola 12 kelas sebagai sebuah tim yang bekerja bersama untuk menemukan sesuatu yang baru bagi anggota kelas (siswa). Sesuatu yang baru datang dari menemukan sendiri, bukan dari apa kata guru. Begitulah peran guru di kelas yang dikelola dengan pendekatan kontekstual.

Model pembelajaran kontekstual merupakan sebuah strategi belajar yang tidak mengharuskan siswa menghafal faktafakta, tetapi sebuah strategi yang mendorong siswa mengkonstruksikan pengetahuan dibenak mereka. Melalui landasan filosofi konstruktivisme, pembelajaran kontekstual "dipromosikan" menjadi alternatif strategi belajar yang baru. Melalui strategi ini, siswa diharapakan belajar melalui "mengalami", bukan "menghafal".

Pendekatan

kontekstual mendasarkan diri pada kecenderungan pemikiran tentang belajar, seperti: (a) proses belajar, (b) transfer belajar, (c) siswa sebagai pembelajar, dan (d) pentingnya lingkungan belajar.

\section{Identifikasi Masalah}

Sesuai dengan latar belakang dan uraian analisis sintuasi maka, identifikasi dan pembatasan masalah dalam pengabdian ini dapat dirumuskan sebagai berikut : Bagaimanakah implikasi penerapan model pembelajaran kontekstual materi batuan dalam meningkatkan hasil belajar siswa pada SMA N 9 Binsus Manado 
Target dan Luaran

\section{Target}

Untuk mengetahui penerapan model pembelajaran kontekstual dalam meningkatkan hasil belajar siswa pada mata pelajaran Geografi di Serkolah Menengah Atas (SMA) Negeri 9 Binsus Manado khusus materi Batuan penyusun litosfer.

\section{Luaran}

Kegiatan ini diharapkan dapat bermanfaat dalam pengembangan keilmuan khususnya mengenai teori dan model-model pembelajaran, hasil belajar dan pengajaran dalam proses belajar mengajar (PBM) Geografi di Sekolah Menengah Atas (SMA). Hasil pelaksanaan pengabdian ini dapat menjadi bahan masukan bagi dosen geografi dan para guru-guru serta pemerintah.

\section{METODE PELAKSANAAN}

\section{Proses Kegiatan Pengabdian}

Proses kegiatan pengabdian ini dirancang dengan menggunakan proses penelitian tindakan kelas (PTK), dengan melalui tahapan sebagai berikut:

1. Tahap Persiapan

Tahapan ini dilalui dalam beberapa langkah kegiatan, meliputi:

- Langkah 1: Menyusun rencana kegiatan penelitian pembelajaran;

- Langkah 2: Menyusun komponen perangkat pembelajaran dengan memprioritas kegiatan belajar Geografi, dengan menggunakan pendekatan kontekstual orientasi pengembangan pola authentic assessment, yang meliputi; bahan ajar, panduan kegiatan PBM, RPP, lembaran kerja dan rancangan evaluasi dalam bentuk format evaluasi/observasi yang berfungsi sebagai instrumen pengamatan aktivitas dan ketrampilan peserta didik dalam proses belajar; dan

- Langkah 3: melakukan orientasi, sekaligus memberikan penjelasan mengenai kegiatan pembelajaran yang akan dilakukan guna menerapkan pendekatan pembelajaran kontekstual dengan orientasi pengembangan pola authentic assessment dalam pengajaran geografi.

2. Tahap pelaksanaan proses pembelajaran dalam pengabdian ini Pada tahap ini, pelaksanaan kegiatan dilakukan dalam bentuk proses pembelajaran dengan pendekatan kontekstual orientasi authentic assessment. Materi dan perangkat pembelajaran merupakan komponen pembelajaran yang sesuai dengan pendekatan kontekstual, dengan rancangan kegiatan sebagai berikut:

- 3 kali kegiatan/pertemuan diamati dengan format evaluasi/ pengamatan aktivitas pembelajaran; 
- 3 kali kegiatan diamati dengan format evaluasi/pengamatan untuk kegiatan kajian batuan;

- laporan kajian dievaluasi dengan format evaluasi laporan kajian lapangan, karya ilmiah berdasarkan hasil kajian dievaluasi dengan format evaluasi karya ilmiah; dan

- 3 kali kegiatan penyajian/ persentasi/diskusi diamati dengan format authentis assessmen penyajian untuk mengetahui kemampuan dalam penyajian dan diskusi. Pokok kegiatan adalah pada pelaksanaan proses pembelajaran termasuk di dalamnya pelaksanaan evaluasi proses terhadap aktivitas dan proses ketrampilan yang ditunjukkan peserta didik selama proses tersebut. Rancangan pola authentic assessment dilakukan untuk mengamati seluruh proses aktivitas peserta didik. Materi bahasan yakni batuan penyausun litosfer.

3. Tahap evaluasi dan pengamatan

Pola evaluasi yang diterapkan adalah evaluasi proses yang dirumuskan sesuai dengan tujuan pembelajaran, dan pelaksanaan evaluasi dirancang dan ditentukan sesuai dengan pokok bahasan, kajian dan ketrampilan yang perlu diamati. Evaluasi inilah yang menggunakan rancangan format authentic assessment, sehingga capaian belajar peserta didik adalah akumulasi dari semua hasil evaluasi yang dilakukan sesuai tahapan yang ditentukan. Kegiatan evaluasi merupakan bagian dari proses pembelajaran, sebab seluruh aktivitas peserta didik dalam proses diamati dengan format yang berisikan indikatorindikator yang akan diamati. Setiap tahapan belajar, diamati dengan menggunakan format yang dilengkapi dengan standar capaian.

4. Tahap analisis dan refleksi

Data yang diperoleh dalam kegiatan evaluasi dan pengamatan dianalisis dan dideskripsikan untuk mengetahui sejauhmana keberhasilan proses pembelajaran yang dilakukan dan melakukan identifikasi kegagalan dan membuat rancangan untuk perbaikan proses pembelajaran selanjutnya. Selanjutnya yang menjadi obyek kajian adalah penerapan pendekatan kontekstual dengan orientasi proses authentic assessment dalam pengajaran Geografi.

\section{HASIL DAN PEMBAHASAN}

\section{Hasil Kegiatan}

\section{Tahap Kegiatan}

Siklus I

Dalam pelaksanaan siklus pengabdian ini, pelaksana menemukan:

1) pada awal siklus ini siswa tampak biasa-biasa saja, karena menerapkan metode mengajar yang biasa 
dipakai yakni metode ceramah di dalam kelas;

2) siswa terlihat agak kaget ketika mengeluarkan beberapa jenis batuan dari tas dan menempelkan chart tentang proses terbentuknya batuan dan skema pengelompkan batuan;

3) ada beberapa siswa yang sibuk mencatat isi chart dan saling tanya tentang jenis batuan yang terletak di meja guru;

4) sebagai motivasi, guru memberikan pertanyaan umpan balik tentang nama batuan yang ditunjukkan satu per satu oleh guru di depan kelas. Ada siswa yang menjawab, tetapi jawabannya tidak benar (Modelling). Contoh: batu pasir dan batu konglomerat disebut batu kali;

5) untuk lebih jelas tentang jenis batuan dan pengelompokkannya siswa diminta mengkaji/membaca buku Geografi sambil menjawab pertanyaan-pertanyaan yang ada pada kartu soal. Ada siswa yang tidak memiliki buku tersebut sehingga harus membaca dan bekerja sama dengan teman semejanya (inquiri, konstruktivisme, masyarakat belajar);

6) sementara menjawab pertanyaanpertanyaan pada kartu soal ada siswa yang mengambil batuan di meja guru; mengamati sambil bertanya tentang nama batuan satu persatu (questioning); dan

7) Pada akhir kegiatan belajar mengajar guru menunjuk empat siswa secara acak untuk menjelaskan tentang apa yang telah dipelajari, tetapi keempat siswa tersebut malu-malu dan takut salah. Setelah dipanggil berulang-ulang oleh guru mereka mengatakan refleksi tetapi singkat sekali (refleksi).

Siklus II

Dalam pelaksanaan siklus pengabdian ini, peneliti menemukan:

1) pada siklus II, siswa mulai aktif, karena diberikan LKS dan dikerjakan secara berkelompok (4 6 orang) serta KBM berlangsung di luar kelas/lingkungan sekolah;

2) setelah mendapat LKS masingmasing kelompok langsung terpencar ke lingkungan sekolah untuk mencari dan mengumpulkan sepuluh macam batu yang berbeda;

3) setiap siswa terlihat membawa buku Geografi sebagai penuntun ketika mereka mengamati batuan;

4) ada kelompok yang secara beramairamai atau mengutus salah satu anggotanya bertanya tentang nama dan warna jenis batuan yang tidak tertulis di dalam buku seperti kwarsa dan tuff; 
5) ada kelompok yang tidak dapat mengumpulkan sepuluh macam batuan;

6) ada kelompok yang salah mengidentifikasi dan mengelomokan jenis batuan, kesalahan tersebut terungkap saat diadakan presentasi hasil kerja tiap kelompok;

7) saat kelompok lain mempresentasikan hasil kerjanya, kelompok yang lain mengikuti sambil membandingkan dengan hasil kerja mereka;

8) dalam sesi tanggapan ada siswa yang memberi tanggapan dan langsung menyalahkan hasil kerja kelompok yang sedang melakukan presentasi. Contoh: batu kapur/gamping bukan batuan metamorf;

9) ada siswa yang mengusulkan agar LKS dan pengamatan dikerjakan secara perorangan; dan

10) saat meminta 5 orang siswa untuk refleksi, kelima siswa tersebut langsung mengadakan refleksi dengan baik.

Siklus III

Dalam pelaksanaan siklus pengabdian ini, peneliti menemukan:

1) pada siklus III, siswa sangat aktif, karena mereka diminta membawa sepuluh macam batu dari rumah masing-masing dan mengerjakan LKS secara individual, walaupun pengerjaannya diperbolehkan bertanya atau bekerja sama dengan teman semejanya;

2) masih ada siswa yang tidak mengumpulkan sepuluh jenis batu;

3) siswa tidak dapat mengidentifikasi dan mengelompokkan jenis batuan dengan benar karena tidak memiliki buku penuntun;

4) pada saat masing-masing siswa mempresentasikan hasil kerjanya (LKS) sambil menunjukkan batuan satu persatu secara individual di depan kelas, suasana kelas menjadi hidup karena secara spontan siswa yang lain menanggapi hasil kerja siswa yang sedang mempresentasikan LKS-nya; (5). ada 88,57 \% atau 31 siswa yang memahami jenis batuan secara benar dilihat dari prestasi dan hasil kerja LKS.

\section{Motivasi dan Interaksi Siswa dalam} Pembelajaran.

Motivasi dan interaksi siswa dalam proses pembelajaran berdasarkan hasil observasi seperti tertera pada Tabel 1. Berdasarkan data Tabel 1, dapat diinterpretasikan bahwa siswa yang mengikuti PBM dari siklus I sampai siklus III stabil. Siswa yang menyimak penjelasan guru dari siklus I sampai siklus III mengalami peningkatan 25,71\%. Siswa yang berhasil mengumpulkan 10 jenis batuan yang berbeda dari siklus II ke siklus III 
mengalami peningkatan $8,57 \%$. Siswa yang aktif melakukan pengamatan dari siklus II ke siklus III mengalami peningkatan 5,57\%. Siswa yang bertanya pada guru atau siswa lain dari siklus I ke siklus II mengalami peningkatan 22,85\%. Sedangkan dari siklus II ke siklus III mengalami peningkatan $11,43 \%$. Siswa yang mengerjakan kartu soal/LKS dari siklus I ke siklus II mengalami peningkatan
31,43 \%, sedangkan dari siklus II ke siklus III stabil. Siswa yang dapat mengidentifikasi jenis batuan berdasarkan warna, bentuk dan kekerasan dengan benar dari siklus II ke siklus III mengalami peningkatan 14,29 $\%$. Siswa yang dapat mengelompokkan jenis batuan dengan benar dari siklus II ke siklus III mengalami peningkatan $11,43 \%$.

Tabel 1 Motivasi dan Interaksi Siswa dalam Proses Pembelajaran

\begin{tabular}{|c|l|c|c|c|c|c|c|}
\hline \multirow{2}{*}{ No } & \multicolumn{1}{|c|}{ Aspek yang diamati } & \multicolumn{2}{c|}{ Siklus I } & \multicolumn{2}{c|}{ Siklus II } & \multicolumn{2}{c|}{ Siklus III } \\
\cline { 3 - 7 } & \multicolumn{1}{|c|}{$\mathbf{F}$} & $\mathbf{0}$ & $\mathbf{F}$ & $\mathbf{\%}$ & $\mathbf{F}$ & $\mathbf{\%}$ \\
\hline 1 & Siswa yang mengikuti PBM & 35 & 100 & 35 & 100 & 35 & 100 \\
\hline 2 & Siswa yang menyimak penjelasan guru & 26 & 74,29 & 35 & 100 & - & - \\
\hline 3 & $\begin{array}{l}\text { Siswa yang berhasil mengumpulkan 10 } \\
\text { jenis batuan yang berbeda }\end{array}$ & - & - & 29 & 82,86 & 32 & 91,43 \\
\hline 4 & Siswa yang aktif melakukan pengamatan & - & - & 32 & 91,43 & 35 & 100 \\
\hline 5 & $\begin{array}{l}\text { Siswa yang bertanya pada guru atau } \\
\text { siswa lain }\end{array}$ & 5 & 14,25 & 13 & 37,14 & 17 & 48,57 \\
\hline 6 & $\begin{array}{l}\text { Siswa yang mengerjakan kartu soal atau } \\
\text { LKS }\end{array}$ & 24 & 68,37 & 35 & 100 & 35 & 100 \\
\hline 7 & $\begin{array}{l}\text { Siswa yang dapat mengidentifikasi jenis } \\
\text { batuan berdasarkan warna, bentuk, dan } \\
\text { kekerasan dengan benar. }\end{array}$ & - & - & 24 & 68,57 & 29 & 82,86 \\
\hline 8 & $\begin{array}{l}\text { Siswa yang dapat mengelompokan jenis } \\
\text { batuan dengan benar }\end{array}$ & - & - & 27 & 77,14 & 31 & 88,57 \\
\hline 9 & $\begin{array}{l}\text { Siswa yang mampu menanggapi } \\
\text { pendapat kelompok/ siswa lain }\end{array}$ & - & - & 4 & 11,43 & 9 & 25,71 \\
\hline 10 & $\begin{array}{l}\text { Siswa yang bekerja sama dengan siswa } \\
\text { lain (saling membantu) }\end{array}$ & 14 & 40 & 29 & 82,86 & 32 & 91,43 \\
\hline 11 & $\begin{array}{l}\text { Siswa yang mampu mempresentasikan } \\
\text { hasil kerjanya dengan benar }\end{array}$ & - & - & 8 & 22,86 & 35 & 100 \\
\hline 12 & $\begin{array}{l}\text { Siswa yang menguasai materi } \\
\text { pembelajaran }\end{array}$ & 17 & 48,57 & 26 & 74,29 & 31 & 88,57 \\
\hline
\end{tabular}

Sumber : data primer yang telah diolah

Siswa yang bekerja sama dengan siswa lain baik secara berpasangan maupun dalam kelompok dari siklus I ke siklus II mengalami peningkatan $42,86 \%$, sedangkan dari siklus II ke siklus III mengalami peningkatan 8,57\%. Siswa yang mampu mempresentasikan hasil kerjanya dengan baik dari siklus II ke siklus III mengalami peningkatan 77,14\%. Siswa yang menguasai materi pembelajaran dari siklus I ke siklus II meningkat 25,72 \%, sedangkan dari siklus II ke siklus III meningkat 14,28\%. Dengan demikian, 
dari 12(dua belas) aspek yang diamati pada setiap siklus ada satu aspek yang tetap/stabil dan 11 (sebelas) aspek lainnya mengalami peningkatan/ perkembangan.

\section{Kemampuan Guru dalam} Melaksanankan Proses Pembelajaran

Berdasarkan hasil observasi kolabolator dapat diperoleh data seperti tertera pada Tabel 2. Berdasarkan data pada Tabel 2, dapat diinterpretasikan bahwa kemampuan guru yang berhasil diamati pada dasarnya mengalami kondisi yang stabil bahkan terjadi perubahan yang pasif pada beberapa aspek, yaitu melakukan motivasi untuk mengetahui kesiapan siswa mengikuti dan berpartisipasi aktif dalam PBM dari siklus I ke siklus II, menggunakan metode yang bervariasi dari siklus I ke siklus II, menggunakan media pengajaran yang bervariasi dari siklus I ke siklus II, menganjurkan penggunaan lingkungan sebagai sumber belajar dari siklus I ke siklus II dan memberikan kesempatan bagi siswa untuk menemukan sendiri, bertanya, dan bekerja sama dalam kelompok dari siklus I ke siklus II.

Tabel 2. Kemampuan Guru dalam Melaksanakan Proses Pembelajaran

\begin{tabular}{|r|l|c|c|c|}
\hline \multicolumn{1}{|c|}{ No } & \multicolumn{1}{|c|}{ Aspek yang diamati } & Siklus I & Siklus II & Siklus III \\
\hline 1 & Melakukan appersepsi & $\mathrm{A}$ & $\mathrm{A}$ & $\mathrm{A}$ \\
\hline 2 & $\begin{array}{l}\text { Melakukan motivasi untuk mengetahui kesiapan siswa } \\
\text { mengikuti PBM (aktif) }\end{array}$ & $\mathrm{B}$ & $\mathrm{A}$ \\
\hline 3 & Menyajikan materi sesuai RP & $\mathrm{A}$ & $\mathrm{A}$ & $\mathrm{A}$ \\
\hline 4 & $\begin{array}{l}\text { Menggunakan metode yang bervariasi antara lain: } \\
\text { leramah, tanya jawab, diskusi/kerja kelompok, } \\
\text { demonstrasi, eksperimen }\end{array}$ & $\mathrm{B}$ & $\mathrm{A}$ \\
\hline 5 & Menggunakan media pengajaran yang bervariasi & $\mathrm{B}$ & $\mathrm{A}$ & $\mathrm{A}$ \\
\hline 6 & Menganjurkan siswa mencari informasi dari buku & $\mathrm{B}$ & $\mathrm{B}$ & $\mathrm{B}$ \\
\hline 7 & Memberikan contoh/model yang dapat ditiru oleh siswa & $\mathrm{A}$ & $\mathrm{A}$ & $\mathrm{A}$ \\
\hline 8 & $\begin{array}{l}\text { Menganjurkan penggunaan lingkungan sebagai sumber } \\
\text { belajar }\end{array}$ & $\mathrm{B}$ & $\mathrm{A}$ & $\mathrm{A}$ \\
\hline 9 & $\begin{array}{l}\text { Mengorganisasikan kelas (berpasangan, berkelompok) } \\
\text { secara bervariasi }\end{array}$ & $\mathrm{B}$ & $\mathrm{B}$ & $\mathrm{A}$ \\
\hline 10 & Menguasai materi yang disajikan & $\mathrm{A}$ & $\mathrm{A}$ & $\mathrm{A}$ \\
\hline 11 & $\begin{array}{l}\text { Memberikan kesempatan bagi siswa untuk menemukan } \\
\text { sendiri, bertanya dan bekerja sama dengan kelompok }\end{array}$ & $\mathrm{B}$ & $\mathrm{A}$ & $\mathrm{A}$ \\
\hline 12 & Membuat rangkuman/simpulan materi pembelajaran. & $\mathrm{A}$ & $\mathrm{A}$ & $\mathrm{A}$ \\
\hline
\end{tabular}

Keterangan : A = Baik sekali, B = Baik, C = Cukup, D = Kurang

Sumber : Data primer yang telah diolah,

\section{Hasil belajar}

Data tentang hasil belajar siswa seperti tertera pada Tabel 3. Berdasarkan data Tabel 3 dapat diinterpretasikan bahwa prestasi belajar dapat dilihat dari perbandingan nilai rata-rata sebelum CAR dan nilai rata-rata sesudah CAR. Pada siklus I meningkat 13,94, dari siklus I ke siklus II meningkat 8,58 dan dari siklus II ke 
siklus III meningkat 4,57. Meningkatnya

nilai rata-rata siswa diperkirakan karena meningkatnya motivasi dan aktivitas belajar siswa melalui penerapan pendekatan CTL.

Tabel 3. Hasil Belajar Siswa

\begin{tabular}{|c|l|c|}
\hline No & \multicolumn{1}{|c|}{ Tahapan Pelaksanaan } & Nilai Rata-rata \\
\hline 1 & Sebelum CAR & 48,77 \\
\hline 2 & Siklus I & 62,71 \\
\hline 3 & Siklus II & 71,29 \\
\hline 4 & Siklus III & 75,86 \\
\hline
\end{tabular}

Sumber : Data Primer yang telah diolah, tahun 2005

\section{Ketuntasan Hasil Belajar Siswa}

Data tentang ketuntasan belajar siswa seperti tertera pada Tabe 4. Berdasarkan data Tabel 4 dapat diinterpretasikan bahwa ketuntasan belajar siswa sebelum CAR dan sesudah CAR terjadi perubahan, dimana sebelum CAR ketuntasan belajarnya 20\% (dari 35 siswa yang mendapat nilai $\geq 65$ sebanyak 7 orang), selanjutnya setelah melaksanakan CAR pada siklus I ketuntasan belajarnya 48,57\% (dari 35 siswa, yang mendapat nilai $\geq 65$ sebanyak 17 orang). Jadi, dari sebelum
CAR ke siklus I mengalami peningkatan 28,57\%. Pada siklus II ketuntasan belajarnya 74,29\% (dari 35 siswa, yang mendapat nilai $\geq 65$ sebanyak 26 orang). Jadi, dari siklus I ke siklus II mengalami peningkatan $25,72 \%$. Pada siklus III ketuntasan belajarnya $88,57 \%$ (dari 35 siswa yang mendapat nilai $\geq 65$ sebanyak 31 orang). Jadi dari siklus II ke siklus III mengalami peningkatan 14,28\%. Adapun secara klasikal, suatu kelas di katakan tuntas jika 85\% dari siswa di dalam kelas tersebut mendapat nilai $\geq 65$.

Tabel 4.Ketuntasan Belajar Siswa

\begin{tabular}{|c|l|c|}
\hline No & \multicolumn{1}{|c|}{ Tahapan Pelaksanaan } & Ketuntasan Belajar \\
\hline 1 & Sebelum CAR & $20 \%$ \\
\hline 2 & Siklus I & $48,57 \%$ \\
\hline 3 & Siklus II & $74,29 \%$ \\
\hline 4 & Siklus III & $88,57 \%$ \\
\hline
\end{tabular}

Sumber : Data primer yang telah diolah..

\section{Pembahasan}

Berdasarkan analisis data hasil di atas, selanjutnya dilakukan pembahasan terhadap hasil ini adalah penerapan CTL dengan lingkungan alam sebagai sumber belajar dapat meningkatkan pemahaman siswa tentang jenis batuan. Kemudian dirinci konsisten dengan masalah pokok, yaitu: Apakah dengan menerapkan pendekatan CTL dan lingkungan sebagai sumber belajar dapat meningkatkan pemahaman siswa dalam pembelajaran geografi khususnya jenis-jenis batuan. penulis membahas penerapan komponen- 
komponen CTL dalam kaitannya dengan pemahaman siswa tentang pembelajaran geografi khususnya jenis-jenis batuan.

\section{Konstruktivisme (Constructivism)}

Dalam penelitian ini, konstruktivisme diterapkan pada semua siklus. Penelitian siklus I, siswa diminta mengerjakan soal-soal yang ada pada kartu soal (kartu soal terlampir) $68,57 \%$ siswa mengerjakan dengan diminta mengerjakan tabel kerja pada LKS. (LKS terlampir ). Seratus persen siswa mengerjakan dengan baik. Siswa yang aktif mengerjakan kartu soal dan LKS dapat langsung memahami jenis batuan. Sesuai dengan inti pembelajaran konstruktivisme, yaitu pengetahuan seseorang hanya dapat dibangun dari diri sendiri (dapat dilihat pada gambar 1; siswa sedang mengamati batuan sambil mengerjakan LKS). benar. Pada siklus II dan III siswa

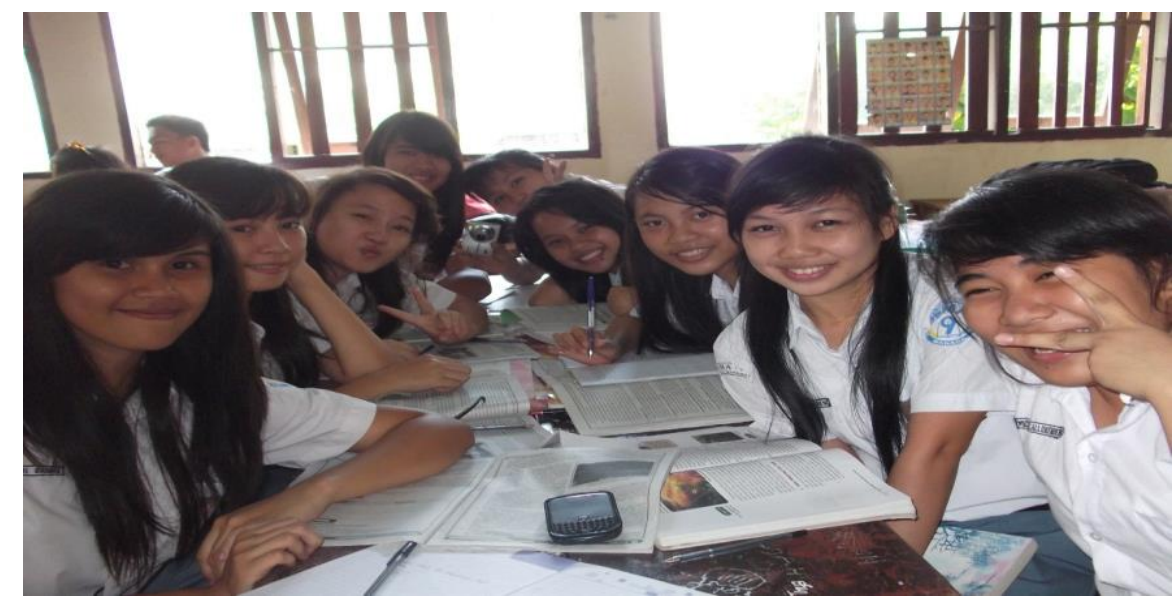

Gambar 1. Siswa sedang mengamati batuan sambil mengerjakan LKS

\section{Menemukan (inquiri)}

Dalam penelitian ini, inquiri diterapkan pada siklus II dan III dengan langkahlangkah sebagai berikut: a) Siswa diminta mengumpulkan 10 jenis batuan yang berbeda di lingkungan sekolah. 91,43\% siswa mampu mengumpulkan 10 jenis batuan, sedangkan 8,57\% siswa tidak mampu mengumpulkan batuan. Alasan yang dikemukakan saat diwawancarai oleh penulis adalah karena keterbatasan waktu yang ditentukan dan ingin mencari jenis batuan yang berbeda dengan kelompok lain. Jenis-jenis batuan yang berhasil dikumpulkan seperti breksi, konglomerat, serpih, kapur, pasir, granit, basalt, apung, obsidian, sabak dan pualam; d) Siswa diminta mengamati jenis batuan yang telah terkumpul pada siklus II, 91,43\% siswa aktif melakukan pengamatan sedangkan 8,57\% siswa tidak aktif, karena tidak memahami apa yang akan diamati. Sedangkan pada siklus III 100\% siswa aktif melakukan pengamatan. 
Berdasarkan quesioner, $100 \%$ siswa dapat menjawab senang dan senang sekali mengamati batuan (dapat dilihat pada gambar 2; siswa sedang mengamati batuan metamorf); c) Siswa diminta mengidentifikasi jenis batuan berdasarkan warna, bentuk dan kekerasannya. Pada siklus II, 68,57\% siswa dapat mengidentifikasi dengan baik sedangkan 31,43\% siswa salah mengidentifikasi, karena tidak memiliki buku paket dan buku siswa (Kejar PS Geografi kelas VII). Sedangkan, pada siklus III, $82,86 \%$ siswa dapat mengidentifikasi jenis batuan dengan benar, sedangkan $17,14 \%$ masih salah mengidentifikasi karena tidak memiliki pengetahuan awal tentang warna dan kristal batuan, misalnya granit berwarna jingga, dan memiliki kristalkristal kasar; d) Siswa diminta mengelompokan jenis batuan ke dalam tiga kelompok yakni batuan beku, batuan sedimen, dan batuan metamorf. $88,57 \%$ siswa dapat mengelompokkan dengan benar. Misalnya, batu sabak dan pualam termasuk jenis batuan metamorf. Komponen ini merupakan inti dari penelitian ini karena dapat mengaktifkan siswa.

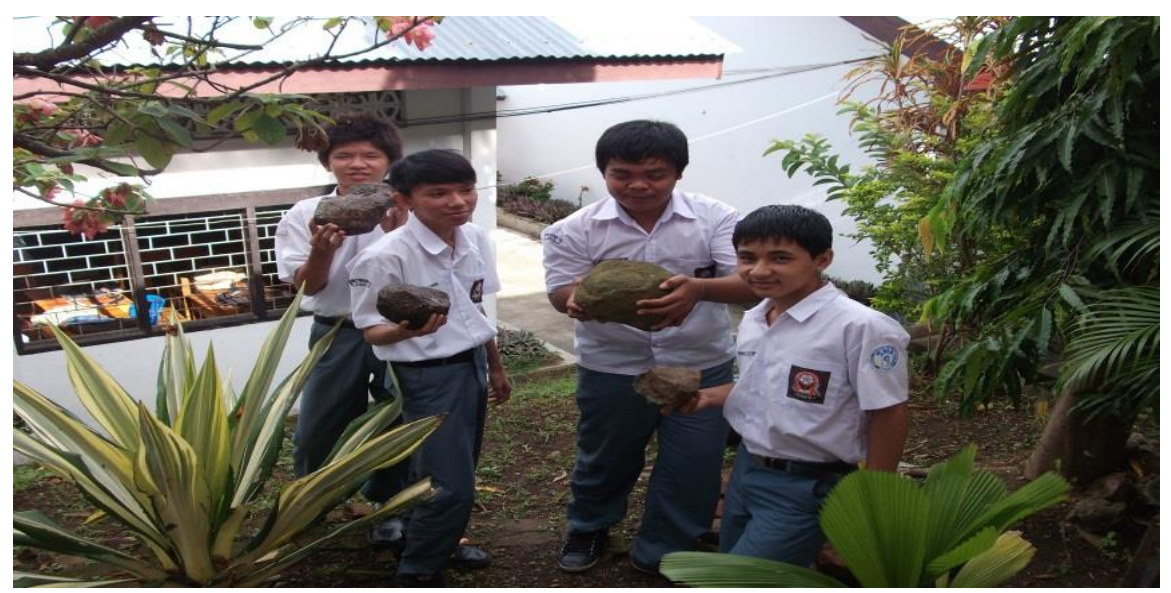

Gambar2. Siswa sedang mengamati batuan metamorf

\section{Bertanya (questioning)}

Komponen ini diterapkan pada semua siklus. Pada siklus I, sebagai motivasi penulis mengajukan pertanyaan tentang nama-nama batuan yang dibawa/ ditunjukkan oleh guru dan jenis batuan lain yang sudah diketahui oleh siswa. Sedangkan, $14,29 \%$ siswa bertanya tentang jenis batuan, nama dan warna batuan yang belum diketahui. Pada siklus III 43,57\% siswa juga bertanya, karena LKS dikerjakan secara individu. Berdasarkan quesioner tanggapan siswa, 48,57\% siswa mengatakan enggan bertanya pada guru karena malu, 11,43\% mengatakan takut diejek, sedangkan 37,14\% mengatakan takut guru marah dan $40 \%$ mengatakan tidak tahu apa yang harus ditanyakan. Pengabdian ini sangat bermanfaat bagi 
penulis, yakni penulis dapat mengetahui sejauh mana siswa memahami tentang jenis batuan dan kemampuan berpikir siswa tentang jenis batuan.

\section{Masyarakat belajar (learning}

\section{community)}

Komponen ini diterapkan pada siklus II dalam penelitian ini, yakni siswa melakukan pengamatan secara berkelompok di lingkungan sekolah dan mengerjakan tabel kerja pada LKS secara bersama-sama. Dalam diskusi kelompok siswa saling kerja sama, mendengar pendapat teman yang sudah tahu tentang jenis batuan atau yang sudah tahu memberi tahu yang belum tahu. Sebaliknya yang belum tahu bertanya kepada yang sudah tahu (belajar dari orang lain). Dapat dilihat pada gambar 5. 3; siswa sedang belajar di lingkungan sekolah secara berkelompok dibimbing oleh guru.

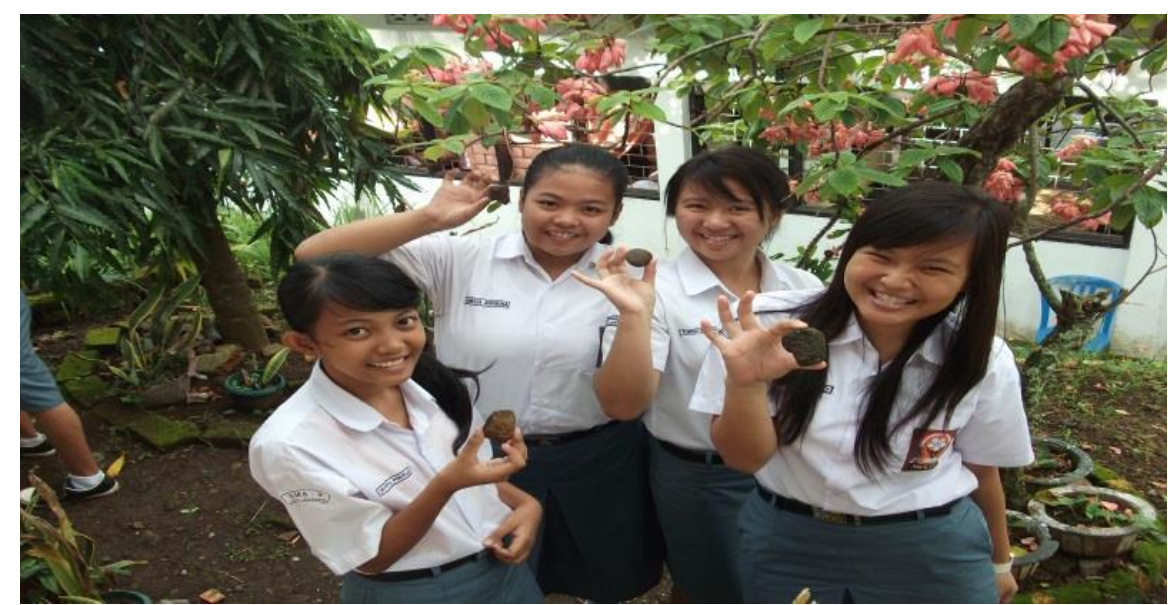

Gambar 3. Siswa sedang belajar di lingkungan sekolah secara berkelompok dibimbing guru

\section{Pemodelan (modelling)}

Dalam penelitian ini, penulis menggunakan jenis batuan nyata sebagai model/contoh yang dapat ditiru oleh siswa. Penerapan pada semua siklus, yaitu penulis membawa batuan ke dalam kelas dan menunjukkan satu persatu kepada siswa sambil menjelaskan (siklus I) atau penulis menunjukkan ciri-ciri batuan dan contohnya di luar kelas/lingkungan sekolah. Pada siklus II dan III siswa yang telah memahami jenis batuan dapat juga memberikan contoh kepada temantemannya. Dengan pemodelan siswa tidak langsung belajar tentang sesuatu yang rill, aktual, kongkrit dan nyata atau tidak abstrak, tekstual, verbal yang dapat ditiru oleh siswa. (dapat di lihat pada gambar

\section{Refleksi (reflection)}

Refleksi pada penelitian ini diterapkan dalam bentuk siswa mempresentasikan hasil kerja kelompoknya oleh salah seorang anggota kelompok pada siklus 
II dan masing-masing individu pada siklus III sambil menunjukkan jenis batuan sesuai tabel kerja pada LKS sementara kelompok/siswa lain menanggapi. Melalui refleksi penulis dapat menilai tingkat pemahaman siswa tentang apa yang telah .

\section{Penilaian yang sebenarnya (assesment)}

Penulis mengumpulkan berbagai data yang dapat memberikan gambaran perkembangan belajar siswa, yaitu dengan menggunakan: a) Penilaian proses pengamatan (terlampir); b) Penilaian aktifitas diskusi kelompok (terlampir); c) penilaian hasil belajar melalui post test.

Suatu kelas dikatakan menerapkan CTL, apabila menerapkan ketujuh komponen CTL. Berdasarkan hasil jawaban quesioner dan wawancara, siswa memberikan penilaian yang positif terhadap pendekatan pembelajaran CTL, yakni 91,43\% menjawab senang sekali apabila pembelajaran geografi disajikan dengan pendekatan CTL dan pengamatan langsung di lingkungan alam/di luar kelas, karena memudahkan siswa dalam memahami konsep-konsep geografi dan tidak kaku.

Penerapan pendekatan CTL dan lingkungan alam sekolah sebagai sumber belajar dapat meningkatkan pemahaman siswa dalam pembelajaran geografi khususnya jenis batuan. Hal ini ditunjukkan dengan meningkatnya nilai rata-rata dari 48,77 menjadi 75,86 dan meningkatnya ketuntasan belajar siswa dari $20 \%$ menjadi $88,57 \%$ setelah classroom action research (CAR). Jadi, secara klasikal kelas VIIa SMP Negeri Tobu dikatakan tuntas belajar geografi khusus untuk sub pokok bahasan jenisjenis batuan, karena 88,57\% siswa mendapat nilai $\geq 65$ atau lebih dari 85\% (standar). Walaupun masih ada empat orang siswa yang belum mencapai ketuntasan individual hal ini dikarenakan faktor ketidakaktifan siswa pada saat mengerjakan LKS.

\section{Keterbatasan Hasil}

Dalam melaksanakan di setiap siklus, penulis menemui hambatan atau keterbatasan sebagai berikut : 1) Siswa belum terbiasa melakukan pengamatan dan mengerjakan LKS, sehingga sulit dan lambat mengerti perintah pada LKS; 2) Buku paket geografi di perpustakaan sekolah yang menguraikan secara rinci tentang batuan sangat terbatas, sehingga siswa hanya menggunakannya saat PBM berlangsung dan tidak bisa dibawa pulang. Hal tersebut tentu menghambat siswa itu sendiri untuk siklus berikutnya; 3) Tidak semua siswa memiliki buku siswa, yakni LKS kejar PS Geografi, sehingga menyulitkan siswa dalam mengamati, mengidentifikasi dan mengelompokan batuan; 4) Cakupan materi yang harus disampaikan cukup 
padat, sedangkan alokasi waktu yang tersedia terbatas. Hambatan ini disiasati dengan cara menggunakan jam akhir KBM agar semua siswa dapat mempresentasikan hasil kerjanya.

\section{KESIMPULAN DAN SARAN}

\section{Kesimpulan}

Berdasarkan uraian yang telah dikemukakan pada bab-bab terdahulu, maka dapat dirumuskan simpulan sebagai berikut:

1. Penerapan pendekatan CTL dan lingkungan alam sebagai sumber belajar dapat meningkatkan pemahaman siswa tentang jenis batuan.

2. Pendekatan CTL sangat cocok untuk pembelajaran geografi khususnya jenis batuan, karena CTL merupakan pembelajaran yang kontekstual, aktual, rill, kongkrit, dan nyata.

3. Pendekatan CTL membuat guru gemar mempelajari konteks yang berkaitan dengan materi pembelajaran, sehingga pembelajaran menjadi aktif, kreatif, efektif, dan menyenangkan. Pengetahuan yang diperoleh dari mengerjakan dan menemukan sendiri melalui pengamatan langsung di lingkungan alam dapat bertahan lebih lama dari mendengar.

\section{Saran}

Mengacu pada simpulan di atas, maka langkah bijaksana yang patut penulis kedepankan relevansinya dengan pengabdian kepada masyarakat adalah:

1. Bagi guru IPS. Geografi yang ingin meningkatkan pemahaman siswa tentang jenis-jenis batuan (geografi fisik) dapat menerapkan pendekatan CTL dan memanfaatkan lingkungan sebagai sumber belajar.

2. Mengawali pembelajaran dengan mengutamakan kontekstual, seorang guru geografi harus gemar mempelajari konteks yang berkaitan dengan materi pembelajaran, sehingga pembelajaran menjadi aktif, kreatif, efektif dan menyenangkan.

3. Kegiatan PTK hendaknya tetap diadakan, karena dapat meningkatkan profesionalisme guru.

\section{KEPUSTAKAAN}

Departemen Pendidikan Nasional 2002. Menejemen Pendidikan Mutu berbasis Sekolah Pembelajaran dan Pengajaran Kontekstual. Depdiknas Jakarta

Nasution, S. 1992 Dikdaktik Asas-Asas Mengajar Jemars. Bandung

Nurhady 2002. Pendekatan Kontekstual . Dirjen Dikdasmen Diknas Jakarta

Pasaribu.I.L. \& B. Simanjuntak 1993. Proses Belajar Mengajar. Tarsito. Bandung.

Sardiman A. M. 1996. Interakasi dan Motivasi Mengajar C.V. Rajawali. Jakarta

Intruktur 2008 Model Model Pembelajaran Efektif . Materi/Bahan Ajar Pelatihan PTK UNIMA. 